\title{
THE EFFECT OF DIIODOTYROSINE ON THE BASAL METABOLISM IN MYXEDEMA ${ }^{1}$
}

\author{
By WILLARD O. THOMPSON, JOSEPH M. ALPER, PHEBE K. \\ THOMPSON AND LOIS F. N. DICKIE \\ (From the Department of Medicine, Rush Medical College, and the \\ Presbyterian Hospital, Chicago)
}

(Received for publication August 22, 1933)

Much speculation has developed concerning the rôle of diiodotyrosine in the thyroid, particularly since the report of its isolation from the gland by Harington and Randall (1) in 1929. According to these authors, the iodine of the thyroid is about equally divided between diiodotyrosine and thyroxine and diiodotyrosine is to be regarded as the precursor of thyroxine. Observations on the biological effects of diiodotyrosine had been started some years before their report. Strouse and Voegtlin (2) in 1909 did not notice any clinical improvement following the administration of 0.1 gram three times a day for ten days and two weeks to a patient with myxedema and to a cretin respectively. Knipping and Wheeler-Hill (3) gave $100 \mathrm{mgm}$. of diiodotyrosine daily by mouth for several weeks to men and observed no effect on the basal metabolism, pulse, weight, or vegetative nervous system. Hoffmann (4) gave 3, 5, diiodo-1-tyrosine subcutaneously to normal men in total doses varying from $100 \mathrm{mgm}$. in one day to 8.4 grams in fourteen days and he likewise observed no effect on the basal metabolism. Beumer and Kornhuber (5) gave 19.5 grams of diiodotyrosine over an eight-day period to a four year old child and noted no influence on diuresis or weight. In a two year old cretin, who had improved greatly on thyroid, a relapse occurred when they gave from 0.5 to 1.0 gram of diiodotyrosine three times daily for eight weeks. The only contradictory observation appears to be that of Abderhalden (6), who reported beneficial results from feeding 3, 5, diiodo-1-tyrosine to three children (siblings) who all showed well marked symptoms of myxedema.

As in the case of man, the data reported on lower animals do not furnish satisfactory evidence of a thyroid-like action of diiodotyrosine. Strouse and Voegtlin (2) observed that it was without effect on the nitrogen metabolism and blood pressure in dogs. Abelin (7) and Gaddum (8) reported that it did not increase the metabolism of normal rats. Abderhalden and Wertheimer (9) showed that while thyroxine reduced the weight rapidly in rabbits and guinea pigs, diiodotyrosine had only a

1 Aided by a grant from the Committee on Scientific Research of the American Medical Association. 
slight effect. Von Zwehl (10) found that the resistance of male white mice to acetonitrile was not noticeably changed by diiodotyrosine. Canzanelli and Rapport (11) have recently reported that diiodotyrosine administered intravenously had a slight effect on the gaseous metabolism of normal female dogs, which, however, amounted to only about one twohundred-and-fortieth of the effect of thyroxine. Abelin (12) has performed various experiments on rats and guinea pigs which have led him to advance the theory that there is a balance in the thyroid between the diiodotyrosine iodine fraction on the one hand and the thyroxine fraction on the other, and that the diiodotyrosine fraction serves as a check on the thyroxine.

The opinion seems to be uniform that diiodotyrosine has qualitatively the same effect as thyroxine on the metamorphosis of tadpoles (6) (12) (13) (14) (15) (16). However, quantitative comparisons were made by Romeis (13), who found that from five hundred to one thousand times as much diiodotyrosine as thyroxine must be used. Gaddum (17) reported that diiodotyrosine has less than one-eighth the activity of diiodothyronine and less than one-thousandth the activity of thyroxine. Abelin and Scheinfinkel (18) claim that dextrorotatory diiodotyrosine, corresponding to the general properties of dextrorotatory amino-acids, was less effective than the levorotatory form. Abderhalden and Schiffmann (6) reported that metamorphosis was also produced by iodized silk peptone, thyreoglobulin, iodovalbumin $\mathrm{D}$, and iodoserumalbumin $\mathrm{A}$ and $\mathrm{D}$ (Blum and Straus). Abelin (19) reported that iodoalbacid is effective and Swingle (20) and Huxley (21), that even inorganic iodine will produce metamorphosis, although this view is not shared by other observers ( 6 ) (18) (22). It is of interest that Rogoff and Marine (23) found that the acid-soluble products of the thyroid gland after alkaline hydrolysis do not cause metamorphosis, whereas the acid-insoluble products do. Because of the great variety of compounds which have been reported to cause metamorphosis, Kendall (24) has been led to conclude that "the essential influence of the iodine compound must be some reaction other than an increase in metabolism similar to that which is brought about by thyroxine." However, it should be pointed out that whenever the fundamental structure of the thyroxine molecule is changed, the amounts of the resulting substances that must be administered to cause the characteristic increase in the rate of reduction of the larval parts are relatively enormous.

Oswald (25) showed that diiodotyrosine splits during tryptic digestion and that after feeding with diiodotyrosine, the amount of iodine in the iodized state in tissues increases. He estimated that of the iodine administered as diiodotyrosine as much as 46 per cent becomes split off in inorganic form. However, Foster and Gutman (26) have recently reported that after feeding of this substance to rabbits, approximately 10 per cent of the total iodine in the urine was recovered as inorganic iodine, 60 per 
cent as unchanged diiodotyrosine, 18 per cent as 3, 5, diiodo-4-hydroxyphenyllactic acid, while 12 per cent could not be isolated. Thus it would appear that a large part of any diiodotyrosine administered either by mouth or intravenously, is available to the tissues as such.

We are unaware of any observations which have been made on the effect of diiodotyrosine on the basal metabolism in patients with myxedema and thought that in particular, it would be desirable to determine definitely whether this substance has any effect when administered by the intravenous route.

\section{DATA}

The observations were made on two patients with well marked myxedema. In the first patient, in whom the disease was spontaneous, no other medication was employed before or during the administration of diiodotyrosine. In the second patient, who developed myxedema following a subtotal thyroidectomy for exophthalmic goiter, the administration of compound solution of iodine in a dose of 5 drops daily was begun sixty-five days before the administration of diiodotyrosine was started and this medication was omitted on the fourth day of administration of diiodotyrosine. This appears, however, to have had no definite effect on the basal metabolism. The d-1 diiodotyrosine of Hoffmann-La Roche was used. It was put into solution by the addition to its suspension in distilled water of a slight excess of 10 per cent sodium hydroxide. It was sterilized by the addition of sufficient merthiolate ${ }^{2}$ to make a dilution of $1: 5000$, except for the first ten injections in the first patient, when it was sterilized by placing the test tube which contained it in boiling water for fifteen minutes. After merthiolate was added, the solution (a total of $5 \mathrm{cc}$.) was allowed to stand twenty minutes before injection. This method of sterilization was employed because the solution turned a dark brown color when it was sterilized on a water bath. The material was always injected intravenously and no unpleasant symptoms were noted following any injection.

In the first patient (Chart 1), a total of 3.7 grams was given in 19 injections over a period of twenty-one days and in the second patient (Chart 2) a total of 5.1 grams in 14 injections over a period of sixteen days. The time and amount of the injections are given in Table 1. The absence of a clear-cut effect on the basal metabolism may be noted in both patients. Thus, in the first patient, the basal metabolism was minus 26 per cent before the injection was started and minus 25 per cent at the end of the period of injection. In the second patient, the basal metabolism was minus 28 per cent on the average before the injections were started

2 One gram of sodium ethylmercurithiosalicylate in $1000 \mathrm{cc}$. of water buffered with 1.4 gram sodium borate in $1000 \mathrm{cc}$. and containing sodium chloride to make the solution approximately isotonic. This preparation was kindly supplied to us by the manufacturers, Eli Lilly and Company, Indianapolis, Indiana. 
and minus 26 per cent at the end of the period of injection. However, if only the figures at the beginning and end of the injections of diiodotyrosine are considered, then the metabolism did increase from minus 34 per cent to minus 26 per cent and the patient lost about $1.5 \mathrm{kgm}$. in weight during this period. These changes may be of no significance, they may

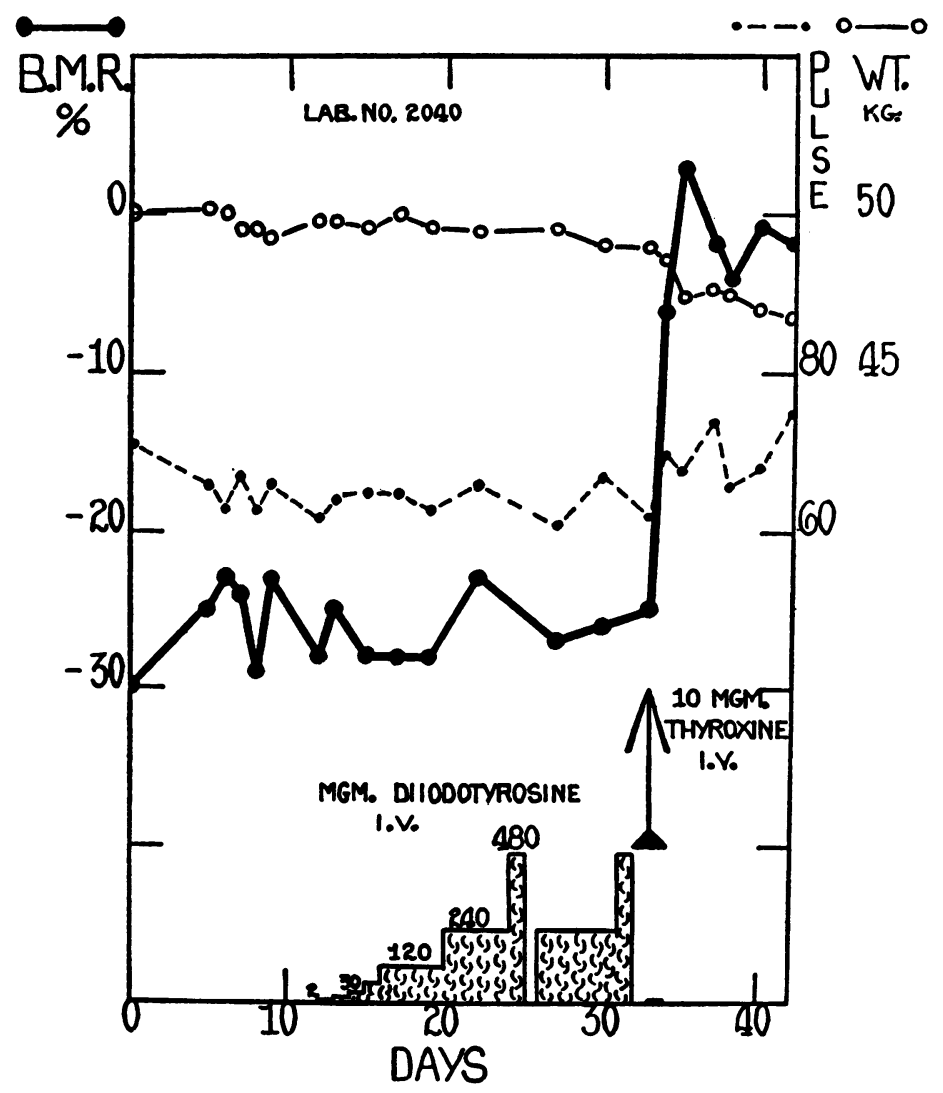

Chart 1. Mrs. M. K. Laboratory Number 2040. Height 152 cm. Age 36

Showing no change in basal metabolism during the intravenous administration (1.v.) of large doses of diiodotyrosine to a patient with spontaneous myxedema and the prompt increase following the intravenous administration of a small dose of thyroxine (arrow).

have been caused by the omission of compound solution of iodine, or they may represent a slight effect from diiodotyrosine. In contrast with the lack of a definite effect from diiodotyrosine is the prompt rise in metabolism following the injection of a relatively minute amount of thyroxine. Thus, in the first patient, $10 \mathrm{mgm}$. of synthetic thyroxine (Hoffmann-La Roche) injected intravenously caused an increase in the metabolism from 
minus 26 per cent to minus 2 per cent and in the second patient, the intravenous injection of $7.5 \mathrm{mgm}$. of thyroxine caused an increase in basal metabolism from minus 26 per cent to minus 7 per cent. The iodine in these doses of thyroxine was only one three-hundred-and-thirty-sixth and one six-hundred-and-eleventh respectively of that in the doses of diiodotyrosine.

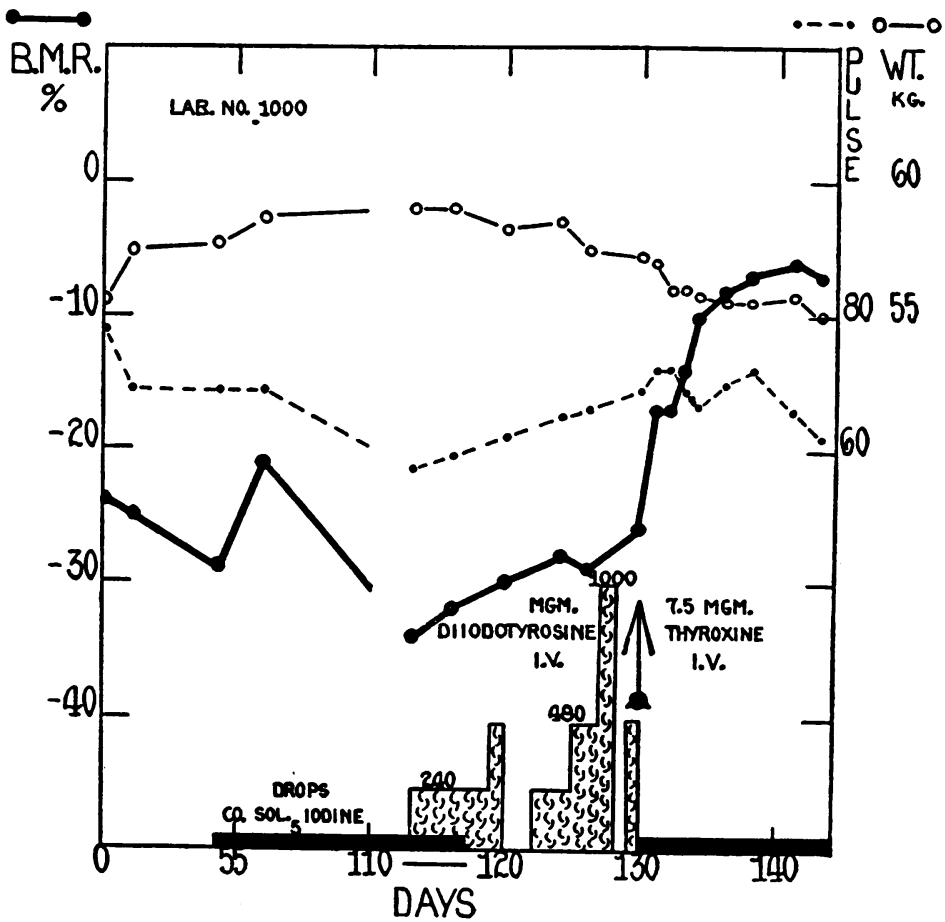

Chart 2. Mrs. A. R. Laboratory Number 1000 . Height 160 cm. Age 33

Showing no definite change in basal metabolism during the intravenous administration of diiodotyrosine to a patient who developed myxedema following a thyroidectomy and the prompt increase following the intravenous administration of a small dose of thyroxine (arrow).

\section{COMMENT}

Since the basal metabolism in the most marked cases of myxedema is from 40 to 45 per cent below the normal and since it was depressed only 26 per cent and 28 per cent below normal in the subjects of this study, it is not improbable that they both had a small amount of functioning thyroid tissue, although none could be felt in either. It is probable that this tissue could affect our results in only two ways: (1) By storing some diiodotyrosine. (2) By using it to form more thyroxine. Even if the normal amount of thyroid tissue were present, the maximum storage capacity for 
TABLE I

Details of administration of diiodotyrosine to two patients with myxedema

\begin{tabular}{|c|c|c|c|}
\hline \multicolumn{2}{|c|}{ Case 1} & \multicolumn{2}{|r|}{ Case 2} \\
\hline Date & $\begin{array}{l}\text { Amount of diiodotyrosine } \\
\text { injected intravenously }\end{array}$ & Date & $\begin{array}{l}\text { Amount of diiodotyrosine } \\
\text { injected intravenously* }\end{array}$ \\
\hline $\begin{array}{cc} & 1932 \\
\text { July } & 18 \\
19 \\
20 \\
21 \\
22 \\
22 \\
23 \\
24 \\
25 \\
26 \\
27 \\
28 \\
29 \\
30 \\
\text { August } 1 \\
2 \\
3 \\
4 \\
5 \\
6\end{array}$ & $\begin{array}{r}m g m . \\
2.1 \\
10.8 \\
30.2 \\
58.9 \\
134.6 \\
120.0 \\
121.6 \\
121.1 \\
241.1 \\
240.3 \\
240.8 \\
240.7 \\
480.3 \\
240.0 \\
241.1 \\
240.6 \\
240.1 \\
240.5 \\
480.3\end{array}$ & $\begin{array}{rr} & 1938 \\
\text { July } & 30 \\
\text { August } 1 \\
2 \\
3 \\
4 \\
5 \\
6 \\
8 \\
9 \\
10 \\
11 \\
12 \\
13 \\
15\end{array}$ & $\begin{array}{r}m g m . \\
240.0 \\
240.1 \\
240.4 \\
240.3 \\
240.2 \\
240.5 \\
480.5 \\
240.2 \\
240.5 \\
240.0 \\
481.0 \\
480.1 \\
1000.6 \\
500.1\end{array}$ \\
\hline Total & 3725. & & 5105. \\
\hline
\end{tabular}

* Compound solution of iodine ( 5 drops daily), was administered from May 26, 1932 to August 2, 1932. Administration of this compound was started again August 16, 1932.

iodine would have been $25 \mathrm{mgm}$. or about $43 \mathrm{mgm}$. of diiodotyrosine. Since the metabolism remained almost stationary, it appears that the output of thyroxine was neither increased nor decreased by the enormous excess of diiodotyrosine administered. In other words, the limiting factor in the output of thyroxine was not the supply of diiodotyrosine; and, as the data on the second patient show, apparently not the supply of iodine. From the observations of Knipping and Wheeler-Hill (3), it appears that a similar conclusion applies to the normal thyroid gland.

If it be true, as Harington and Randall (1) claim, that diiodotyrosine is the precursor of thyroxine, then two conclusions may be drawn from our data: (1) Diiodotyrosine probably cannot affect the metabolism without being synthesized into thyroxine. (2) This synthesis does not appear to take place in the tissues of the body outside of the thyroid gland. Our data, together with those of Gaddum (8) reported above, serve to emphasize the importance of preserving the integrity of the thyroxine molecule if its characteristic results are to be produced. Even the work on tadpoles 
would appear to support this conclusion, because of the enormous quantity of other substances required to cause metamorphosis in contrast with the relatively minute amounts of thyroxine. The reason for the apparent difference in the effect of very large doses of diiodotyrosine in tadpoles and man is not clear. Means, Lerman and Salter (27) have recently advanced the hypothesis that diiodotyrosine assumes calorigenic properties when linked with amino-acids in iodothyreoglobulin.

\section{SUMMARY}

In one patient with myxedema the administration of 3.7 grams of diiodotyrosine in nineteen intravenous injections over a period of 21 days was without effect on the basal metabolism; and in another patient with myxedema (who was also receiving compound solution of iodine for the first four days) the administration of 5.1 grams in fourteen intravenous injections over a period of 15 days was without a definite effect on the basal metabolism.

In patients with a small amount of functioning thyroid tissue the limiting factor in the output of thyroxine does not appear to be the supply of diiodotyrosine.

It would appear that diiodotyrosine cannot be synthesized into thyroxine outside of the thyroid gland.

\section{BIBLIOGRAPHY}

1. Harington, C. R., and Randall, S. S., Observations on the iodine-containing compounds of the thyroid gland. Isolation of $d l-3: 5-$ diiodotyrosine. Biochem. J., 1929, 23, 373.

2. Strouse, S., and Voegtlin, C., Studies concerning the iodine-containing principle of the thyroid gland. I. Pharmacological action and therapeutic behavior of diiodotyrosine. J. Pharmacol. and Exper. Therap., 1909, 1, 123.

3. Knipping, H. W., and Wheeler-Hill, E., Beitrag zur medikametösen Fettsuchtbehandlung. Deutsches Arch. f. klin. Med., 1926, 153, 223.

4. Hoffmann, F., Untersuchungen über Dijodthyrosin und Schilddrüsensubstanz, zugleich einige technische Bemerkungen über die Gasstoffwechselmethode nach Knipping. Ztschr. f. d. ges. exper. Med., 1927, 57, 68.

5. Beumer, H., and Kornhuber, B., Ueber die Wirkung des Diiodtyrosins im Stoffwechsel und bei Myxödem. München med. Wchnschr., 1925, 72, 2057.

6. Abderhalden, E., and Schiffmann, O., Studien über die von einzelnen Organen hervorgebrachten Substanzen mit spezifischer Wirkung. IX. Mitteilung. Pflüg. Arch. f. d. ges. Physiol., 1923, 198, 128.

7. Abelin, J., Beiträge zur Kenntnis der physiologischen Wirkung der proteinogenen Amine. VII. Mitteilung. Uber den Einfluss des Diiodtyrosins, des Diiodtyramins und des Hordenins auf den Gaswechsel. Biochem. Ztschr., 1923, 138, 161.

8. Gaddum, J. H., Quantitative observations on thyroxine and allied substances. II. Effects on the oxygen consumption of rats. J. Physiol., 1930, 68, 383. 
9. Abderhalden, E., and Wertheimer, E., Studien über die Wirkung des Thyroxins auf den tierischen Organismus und insbesondere auf die Wärmeregulation des Gleichwarmblüters. Arch. f. d. ges. Physiol., 1928, 219, 588.

10. Von Zwehl, T., Beiträge zur Wirkung des Dijodtyrosins im Säugetierversuch. Arch. f. Entwcklngsmechn. d. Organ., 1926, 107, 456.

11. Canzanelli, A., and Rapport, D., The comparative effects upon metabolism of intravenously injected tyrosine, diiodotyrosine, diiodothyronine and thyroxine. Am. J. Physiol., 1933, 103, 279.

12. Abelin, I., Einfluss des Dijodtyrosins auf den hyperthyreotischen Stoffwechsel. Biochem. Ztschr., 1931, 233, 483.

13. Romeis, B., Quantitative Untersuchungen über die Wirkung von Thyroxin, Dijodtyrosin, Jodothyrin und Jodthyreoglobulin. Klin. Wchnschr., 1922, $1,1262$.

14. Morse, M., The effective principle in thyroid accelerating involution in frog larvae. J. Biol. Chem., 1914, 19, 421.

15. Hoffman, O., and Gudernatsch, F., Differentiation as effected by diiodotyrosine plus certain other amino acids. Endocrinology, 1933, 17, 239.

16. Swingle, W. W., Is the tadpole test for thyroid valid? Endocrinology, 1924, 8, 832 .

17. Gaddum, J. H., Quantitative observations on thyroxine and allied substances. I. The use of tadpoles. J. Physiol., 1927, 64, 246.

18. Abelin, J., and Scheinfinkel, N., Uber das Verhalten der Schilddrüsenstoffe und des Dijodtyrosins im Organismus. Ergebn. d. Physiol., 1925, 24, 690.

19. Abelin, J., Uber den Einfluss spezifisch gebauter Jodverbindungen auf die Metamorphose von Froschlarven und vom Axolotl. Biochem. Ztschr., $1921,116,138$.

20. Swingle, W. W., Studies on the relation of iodine to the thyroid. J. Exper. Zool., 1918-19, 27, 397, 417.

21. Huxley, J. S., Studies on amphibian metamorphosis. II. Proc. Roy. Soc., B, 1925, 98, 113 (Quoted Gaddum).

22. Uhlenhuth, E., The effect of iodine and iodothyrin on the larvae of salamanders. III. The rôle of the iodine in the specific action of the thyroid hormone as tested in the metamorphosis of the axolotl larvae. Biol. Bull., 1922, 42, 143.

23. Rogoff, J. M., and Marine, D., Effect on tadpoles of feeding thyroid products obtained by alkaline hydrolysis. J. Pharmacol. and Exper. Therap., 1916, 9, 57.

24. Kendall, E. C., Thyroxine. The Chemical Catalog Company, Inc., New York, 1929.

25. Oswald, A., Uber den Abbau des Diiodtyrosins im tierischen Organismus. Ztschr. f. physiol. Chem., 1910, 65, 141.

26. Foster, G. L., and Gutman, A. B., On the fate of diiodotyrosine in the animal organism. J. Biol. Chem., 1930, 87, 289.

27. Means, J. H., Lerman, J., and Salter, W. T., The rôle of thyroxin iodine and total organic iodine in the calorigenic action of whole thyroid gland. J. Clin. Invest., 1933, 12, 683. 